\title{
IASI observations of seasonal and day-to-day variations of tropospheric ozone over three highly populated areas of China: Beijing, Shanghai, and Hong Kong
}

\author{
G. Dufour ${ }^{1}$, M. Eremenko ${ }^{1}$, J. Orphal ${ }^{1,2}$, and J.-M. Flaud ${ }^{1}$ \\ ${ }^{1}$ Laboratoire Inter-universitaire des Systèmes Atmosphériques (LISA), UMR 7583, Universités Paris-Est et Paris 7, CNRS, \\ Créteil, France \\ ${ }^{2}$ Institut für Meteorologie und Klimaforschung, Karlsruhe Institute of Technology (KIT), Germany
}

Received: 7 August 2009 - Published in Atmos. Chem. Phys. Discuss.: 2 November 2009

Revised: 13 April 2010 - Accepted: 20 April 2010 - Published: 23 April 2010

\begin{abstract}
IASI observations of tropospheric ozone over the Beijing, Shanghai and Hong Kong areas during one year (2008) have been analysed, demonstrating the capability of space-borne infrared nadir measurements to probe seasonal and even day-to-day variations of lower tropospheric ozone ( $0-6 \mathrm{~km}$ partial columns) on the regional scale of highly populated areas. The monthly variations of lower tropospheric ozone retrieved from IASI clearly show the influence of the Asian summer monsoon that brings clean air masses from the Pacific during summer. They exhibit indeed a sharp ozone maximum in late spring and early summer (May-June) followed by a summer minimum. The time periods and the intensities of the maxima and of the decreases are latitudedependent: they are more pronounced in Hong Kong and Shanghai than in Beijing. Moreover, IASI provides the opportunity to follow the spatial variations of ozone over the surroundings of each megacity as well as its daily variability. We show here that the large lower tropospheric ozone amounts $(0-6 \mathrm{~km}$ partial columns) observed with IASI are mainly downwind the highest populated areas in each region, thus possibly suggesting the anthropogenic origin of the large ozone amounts observed. Finally, an analysis of the mean ozone profiles over each region - for selected days with high ozone events - in association with the analysis of the meteorological situation shows that the high ozone amounts observed during winter are likely related to descents of ozonerich air from the stratosphere, whereas in spring and summer the tropospheric ozone is likely enhanced by photochemical production in polluted areas and/or in air masses from fire plumes.
\end{abstract}

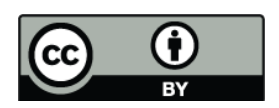

Correspondence to: G. Dufour (dufour@lisa.univ-paris12.fr)

\section{Introduction}

Ozone $\left(\mathrm{O}_{3}\right)$ is a key trace gas in the troposphere that plays a significant role in atmospheric chemistry, air quality and atmospheric radiative forcing. It is not only an important greenhouse gas (Fishman et al., 1979), but also a secondary pollutant produced by the photochemical oxidation of hydrocarbons and carbon monoxide in presence of nitrogen oxide radicals $\left(\mathrm{NO}+\mathrm{NO}_{2}\right)$. Ozone controls the oxidizing capacity of the atmosphere being the primary precursor of the hydroxyl radical $(\mathrm{OH})$ which is the main oxidant in the troposphere. Surface ozone at high concentrations is a pernicious pollutant that causes damages to human health and vegetation (Seinfeld and Pandis, 1997).

Background tropospheric ozone concentrations have been increasing for over a century especially in the Northern Hemisphere (Vingarzan, 2004). This increase is partly related to the growth of the emissions of ozone precursors $\left(\mathrm{NO}_{\mathrm{x}}\right)$. Although trends in tropospheric ozone vary both in sign and in magnitude depending on the considered regions, background ozone levels in northern midlatitudes have continued to rise over the last decades (Vingarzan, 2004; Oltmans et al., 2006). In Europe, North America and Japan, tropospheric ozone levels increased in the 1970s and in the 1980s, but the increase has slowed down since the 1990s, and ozone levels even started to decrease in some regions, partly due to emission regulations applied in these countries (Oltmans et al., 2006). On the contrary, due to the rapid development of East Asia and in particular China, emissions of ozone precursors, that were still at low concentrations in the 1970s, have rapidly increased in the past decade (Richter et al., 2005) and are now larger than the North American and European emissions (Akimoto, 2003). Therefore, the

Published by Copernicus Publications on behalf of the European Geosciences Union. 
tropospheric ozone amounts produced over China are increasing, thus having a significant regional influence on the temporal and spatial variabilities of air quality in East Asia, but also up to the hemispheric scale due to the long-range transport across the Pacific (e.g. Jacob et al., 1999). Hence, monitoring of tropospheric ozone in this region of the world is important to quantify its sources and its impact on air quality, and in order to better evaluate its trend and the impact of long-range transport.

In the last years, the number of ozone measurements and studies focusing on China has significantly increased either through routine measurements (Chan et al., 1998; Xu et al., 1997; Ding et al., 2008; Lam et al., 2001; Lin et al., 2008; Lin et al., 2009; Wang et al., 2009) or through dedicated measurement campaigns (Liu et al., 1999) and through model studies (Liu et al., 2002; Li et al., 2007; He et al., 2008). The seasonal variations of surface ozone and the influence of the air masses origin as well as the role of the monsoon especially during summer have been studied for different regions of China (Xu et al., 1997; Liu et al., 2002; Ding et al., 2008; Lin et al., 2009). Also relatively long time-series of ozone measurements were reported for example for Hong Kong (e.g. Wang et al., 2009) and Beijing (e.g. Ding et al., 2008). However, these different studies are mainly based on surface or aircraft measurements with limited spatial coverage, leading to a persistent question about the representativeness of the sites at the regional scale.

The spatial coverage of the new generation of nadirlooking instruments onboard polar-orbiting satellites (e.g. IASI, GOME2, TES, OMI) makes them interesting tools to monitor tropospheric ozone over large regions, helping then to assess the problems related to air quality and transport. However retrieving tropospheric ozone from satellite observations is a challenging task because only a small part of the total atmospheric ozone is contained in the troposphere. The first satellite measurements of tropospheric ozone were obtained using ultraviolet-visible sounders (e.g. Fishmann et al., 2003; Liu et al., 2005) but this type of measurements has limitations in the mid- and high latitudes. On the other hand, the recent development of infrared nadir sounders allows accurate measurements of tropospheric ozone, with the advantage that the measurements are also possible during the night. The first demonstration of tropospheric ozone column retrievals from infrared nadir spectra was made using the IMG (Interferometric Monitor for Greenhause gases) instrument (Turquety et al., 2002, Coheur et al., 2005). Later on, the TES (Tropospheric Emission Spectrometer) instrument aboard the EOS-Aura satellite has also provided measurements of tropospheric ozone (Worden et al., 2007) with first applications to air quality (Jones et al., 2008) and climate modelling (Worden et al., 2008). Recently, using measurements from the IASI (Infrared Atmospheric Sounding Interferometer) instrument aboard the European Metop-A satellite (launched in October 2006), tropospheric ozone during the heat wave over Europe in summer 2007 has been ob-

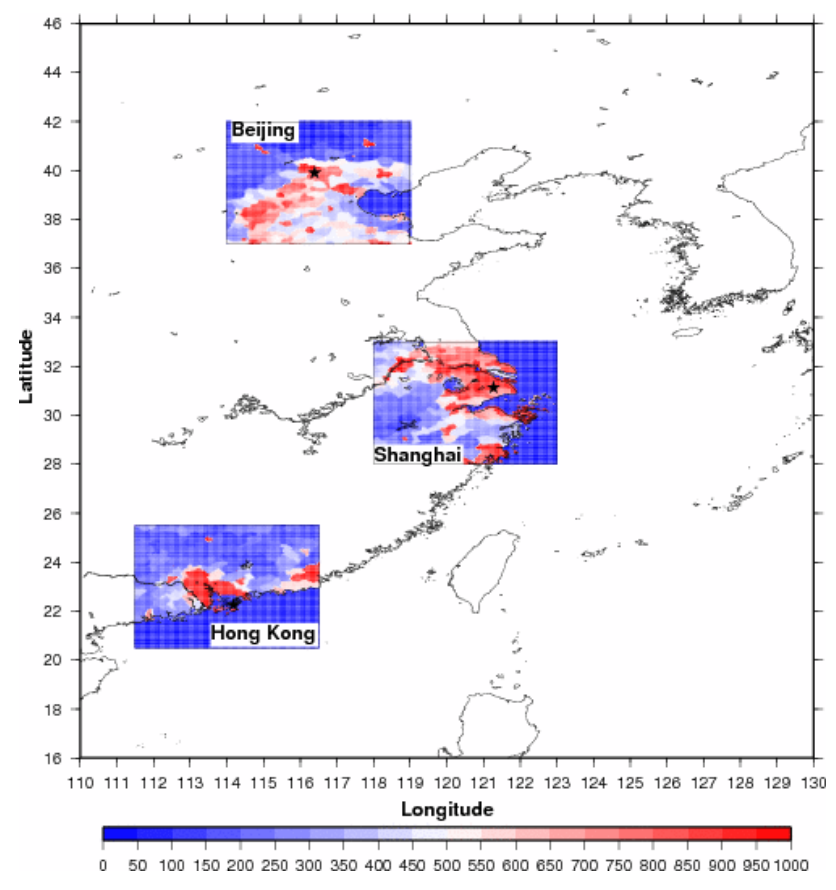

Fig. 1. Regions of $5^{\circ} \times 5^{\circ}$ in latitude and longitude around Beijing, Shanghai and Hong Kong considered for the present study with the population density indicated for each region. The population density, in persons per $\mathrm{km}^{2}$, is given for 2005 (CIESIN, 2005).

served and compared with balloon sondes and predictions from a photochemical tropospheric model (Eremenko et al., 2008), demonstrating the potential of IASI measurements for air quality applications. It is worth noticing indeed that in contrast to TES, IASI has an excellent spatial coverage and is therefore well suited for measurements of tropospheric ozone with an air quality focus.

In this paper, we investigate the ability of the IASI instrument to monitor lower tropospheric ozone at the regional scale. We choose three highly populated Chinese regions (limited to $5^{\circ}$ in latitude and longitude): the northern part of the North China Plain (Beijing), the Yangtze River Delta (Shanghai), and the Pearl River Delta (Hong Kong) (Fig. 1). In particular we evaluate the possibilities of retrieving the seasonal variations of tropospheric ozone and also of probing its day-to-day variations. These regions have been selected because they enclose the largest Chinese megacities and large industrial regions (the Pearl River Delta is the world's major consumer goods manufacturing base) and because they lie in different latitudes from the tropics to the midlatitudes. The analyses are based on the first complete year of IASI operation: the year 2008. Note that only the morning overpasses of the satellite are considered in this study. In the second section, the IASI instrument is described, the retrieval procedure is summarized, and the performances of the ozone retrievals are discussed. The third and fourth sections report on the seasonal variations of tropospheric ozone observed by IASI 
in the three regions and on its day-to-day variations, respectively.

\section{The IASI observations}

\subsection{The IASI instrument}

The IASI (Infrared Atmospheric Sounding Interferometer) (Clerbaux et al., 2009) instrument is a nadir-viewing spectrometer onboard the European MetOp-A satellite. This satellite, launched in October 2006, flies in a polar sunsynchronous orbit (about $800 \mathrm{~km}$ altitude) and crosses the equator at two fixed local solar times 9:30 a.m. (descending mode) and 9:30 p.m. (ascending mode). The IASI instrument is a Fourier-transform spectrometer with a 2-cm optical path difference covering the $645-2760 \mathrm{~cm}^{-1}$ spectral range. The apodized spectral resolution is $0.5 \mathrm{~cm}^{-1}$ (full-width at halfmaximum). The radiometric accuracy in noise-equivalent radiance temperature at $280 \mathrm{~K}$ is $0.20 \mathrm{~K}$ at $650 \mathrm{~cm}^{-1}$ and $0.47 \mathrm{~K}$ at $2400 \mathrm{~cm}^{-1}$. IASI measures the thermal infrared radiation emitted by the Earth's surface and the atmosphere. The instrument scans the surface perpendicular to the satellite's flight track with 15 individual views on each side of the track (across-track). The maximum scan angle of $48.3^{\circ}$ from the nadir corresponds to coverage of about $2200 \mathrm{~km}$ acrosstrack for one swath.

The distance between two successive overpasses is $25^{\circ}$ in longitude (i.e. $2800 \mathrm{~km}$ at the equator). Then, for latitudes higher than $45^{\circ}$, the footprints of two successive overpasses overlap. At the nadir point, the ground pixel size (total fieldof-view) is $50 \times 50 \mathrm{~km}^{2}$. The total field-of-view is composed of 4 individual ground pixels with $12 \mathrm{~km}$ diameter each.

The primary objectives of the IASI instrument are to deliver meteorological products (surface temperature, temperature and humidity profiles, and cloud information). However the large spectral coverage, the high radiometric sensitivity and accuracy, and the rather high spectral resolution of the instrument allow deriving global distributions of several important trace gases (such as $\mathrm{O}_{3}, \mathrm{CO}, \mathrm{NH}_{3}, \ldots$ ) at high spatial resolution (e.g. Eremenko et al., 2008; Boynard et al., 2009; Forêt et al., 2009; Keim et al., 2009; Massart et al., 2009; George et al., 2009; Fortems-Cheiney et al., 2009; Turquety et al., 2009; Clarisse et al., 2009).

\subsection{The retrieval method}

The retrievals were performed using the radiative transfer model KOPRA (Karlsruhe Optimised and Precise Radiative transfer Algorithm) and its inversion module KOPRAFIT (Stiller et al., 2000), both adapted to the nadir-viewing geometry. A constrained least squares fit method with an analytical altitude-dependent regularization is used. The regularization method applied as well as the error calculations are detailed in Eremenko et al. (2008). To summarize, the regularization matrix is a combination of zero, first and second order Tikhonov constraints (Tikhonov, 1963) with altitudedependent coefficients. The coefficients are optimized both to maximize the degrees of freedom (DOF) of the retrieval and to minimize the total error on the retrieved profile. For the Beijing region the regularization matrix used in this study is the same as the one used in Eremenko et al. (2008), i.e. determined for summer midlatitude conditions. Note that the results of a validation study (Keim et al., 2009) show that, while the regularization matrix was built up for the summer period, it is valid as well also for the other seasons. Shanghai and Hong Kong lie in the tropics and the altitudedependent regularization defined for the midlatitudes is not well adapted in this case, especially because the tropopause height is higher in the tropics. Accordingly a regularization matrix has then been set up for the tropical conditions using the same procedure as for the midlatitudes (Eremenko et al., 2008). The a priori profiles used during the retrievals are compiled from the climatology of McPeters et al. (2007) and are typical for the midlatitudes (Beijing) and for the 20$40^{\circ} \mathrm{N}$ and the $10^{\circ}-30^{\circ} \mathrm{N}$ latitude bands for Shanghai, and Hong Kong, respectively. The same a priori profile has been used for all seasons and only the morning overpasses have been considered.

The analysis of IASI data is performed in three steps. First, the effective surface temperature is retrieved from selected spectral windows between 800 and $950 \mathrm{~cm}^{-1}$ assuming a blackbody with an emissivity equal to unity. In the second step, the atmospheric temperature profile is retrieved from $\mathrm{CO}_{2}$ lines in the $15 \mu \mathrm{m}$ spectral region and using the ECMWF profiles as a priori. In the third step, the ozone profiles are retrieved from seven spectral windows located in the $975-1100 \mathrm{~cm}^{-1}$ region, in order to avoid strong water vapor lines. The spectroscopic parameters of the different species are from HITRAN 2004 (Rothman et al., 2005). Note that before starting the retrievals, the IASI spectra are filtered for cloud contamination. The cloud filter is based on tests on the retrieved surface temperature and on the shape of the baseline of the spectra (Eremenko et al., 2008). Only spectra for clear sky conditions are considered. A quality flag is also applied to the retrieved products to discard unphysical results (negative values, large oscillations).

The error budget, calculated for each individual retrieved profile (see Eq. (3) in Eremenko et al., 2008) accounts for errors due to the measurement noise, the uncertainty in the temperature profile, the smoothing error and all the other systematic errors (e.g. uncertainty in spectroscopy). The corresponding total error in each retrieved concentration is about $30 \%$ on average from the surface up to $6 \mathrm{~km}$ and ranges between 35 and $45 \%$ from $6 \mathrm{~km}$ up to the tropopause. The main contribution to the total error is the smoothing error. The total error in the columns is calculated from the error budget determined for the profile (see Eq. (4) in Eremenko et al., 2008). In fact the error on each retrieved concentration translates to a total error onto the $0-6 \mathrm{~km}$ columns that ranges from 10 to $20 \%$ - corresponding to less than 3 Dobson Units (DU) - 

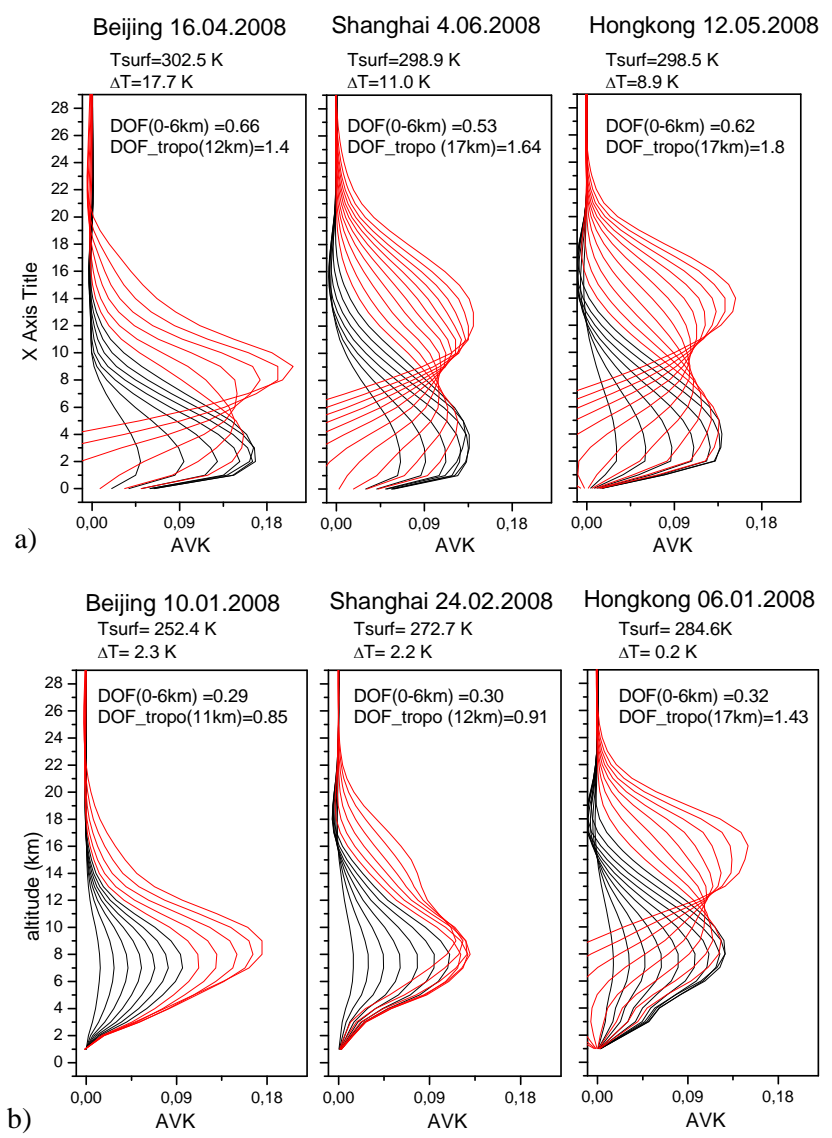

Fig. 2. Example of tropospheric averaging kernels derived from IASI observations above Beijing, Shanghai and Hong Kong a) for favorable thermal conditions (spring) and b) for unfavorable thermal conditions (winter). The retrieved effective surface temperature, thermal contrast and the degrees of freedom up to $6 \mathrm{~km}$ and up to the tropopause height are indicated for each case. The averaging kernels are given for the retrieval grid ( $1 \mathrm{~km}$ spacing). They are represented in black for the levels up to $6 \mathrm{~km}$ and in red for the levels above.

for the 3 regions considered in the paper. A validation exercise performed over the first one-year-and-a-half of IASI operation for the northern midlatitudes shows that no significant bias (less than 5\%) exists in the retrieved columns and that the errors derived from the error budget calculation are consistent with the standard deviation of the differences between sonde measurements and IASI observations (Keim et al., 2009).

Examples of tropospheric averaging kernels are presented in Fig. 2 for each of the three regions considered in the present study. They are given on the retrieval altitude grid that is a $1-\mathrm{km}$ grid. Two cases are illustrated. The first case (Fig. 2a) represents averaging kernels that are obtained for favorable thermal conditions (high surface temperature, large thermal contrast) which enhance the sensitivity of the ozone retrieval in the lower troposphere. The degrees of freedom
Table 1. Degrees of freedom from the surface up to the mean tropopause height averaged over the year 2008 with the associated standard deviation $(\sigma)$, mean daily minimum ( $\min )$ and mean daily maximum (max).

\begin{tabular}{lllll}
\hline & Mean & $\sigma$ & $\min$ & $\max$ \\
\hline Beijing & 1.21 & 0.10 & 0.92 & 1.43 \\
Shanghai & 1.36 & 0.10 & 0.99 & 1.56 \\
Hong Kong & 1.49 & 0.08 & 1.23 & 1.65 \\
\hline
\end{tabular}

are about 0.6 for the $0-6 \mathrm{~km}$ partial columns and range between 1.4 and 1.8 for the total tropospheric columns. Figure 2a suggests that the ozone from the lower and the upper troposphere can be separated using the IASI observations in the case of favorable thermal conditions. The limit between these two distinguishable parts of the troposphere is about $6 \mathrm{~km}$ for Beijing and about $8-9 \mathrm{~km}$ for Shanghai and Hong Kong (Fig. 2a). The averaging kernels of the lower tropospheric ozone have a maximum between 2 and $3 \mathrm{~km}$ for Beijing and a little higher (between 3 and $4 \mathrm{~km}$ ) for Shanghai and Hong Kong. This shape of averaging kernels (Fig. 2a) occurs typically during spring and summer when the surface temperature and the thermal contrast are sufficiently high to increase the sensitivity to the lowest layers of the atmosphere. For comparison, we plot in Fig. 2b examples of averaging kernels for the three regions with the lowest degrees of freedom in the lower troposphere (0-6 km columns). This corresponds to winter observations. In this case, the degrees of freedom are about 0.3 for the $0-6 \mathrm{~km}$ partial columns and range from 0.85 to 1.43 for the total tropospheric columns. The thermal contrast and the surface temperature are low (between 0 and $2 \mathrm{~K}$ for the thermal contrast), leading to less sensitivity to the troposphere. For this kind of observations, the sensitivity of the infrared measurement is not sufficient to separate the information coming from the lower and the upper part of the troposphere, especially in Beijing and Shanghai. The averaging kernels have their maximum between 7 and $9 \mathrm{~km}$ leading to the fact that the observations are mostly sensitive to the free and the upper troposphere. In Hong Kong, the situation is different as the tropopause height is high and almost does not vary with the seasons. In this case, two different partial columns can be separated: a "free" tropospheric column with a maximum sensitivity around $8 \mathrm{~km}$, and an upper tropospheric/lower stratospheric column (Fig. 2b). However it is worth noting that the averaging kernels presented in Fig. $2 b$ are typical for the worst cases of one year observation over each region. Table 1 presents the degrees of freedom averaged over the year from the surface up to the mean annual tropopause altitude (obtained from NCEP analyses). The daily mean values range from 0.92 to 1.43 for Beijing, from 0.99 to 1.56 for Shanghai, and from 1.23 to 1.65 for Hong Kong. 

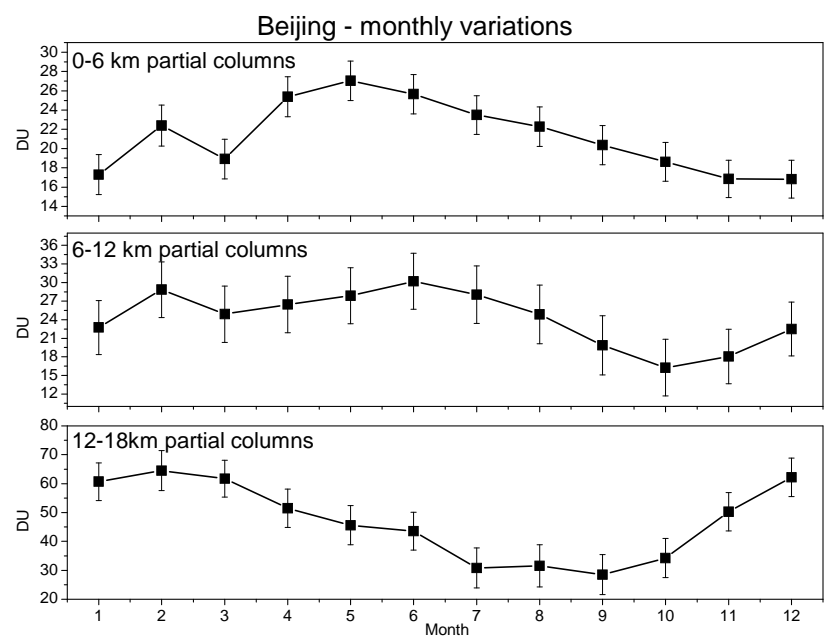

Fig. 3. Monthly mean variations of different partial columns $(0-$ $6 \mathrm{~km}$ column, $6-12 \mathrm{~km}$ column and $12-18 \mathrm{~km}$ column) retrieved from IASI observations over Beijing in 2008.

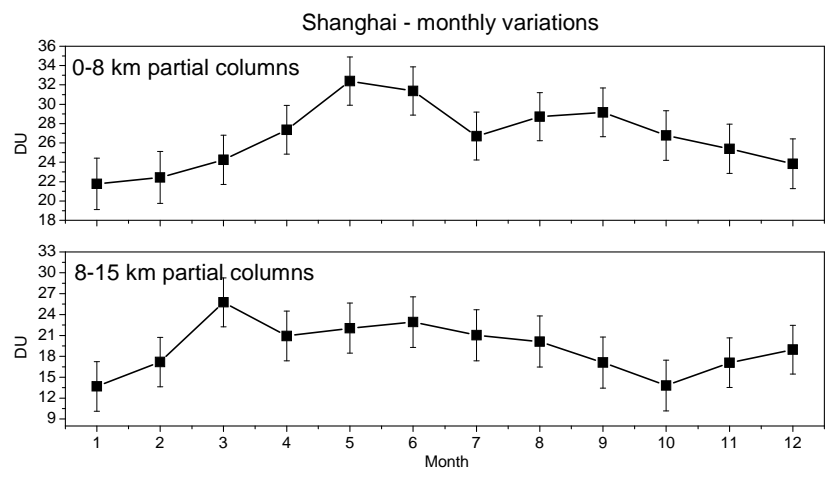

Fig. 4. Monthly mean variations of different partial columns (0$8 \mathrm{~km}$ column, and $8-15 \mathrm{~km}$ column) retrieved from IASI observations over Shanghai in 2008.

Note that in both cases (thermal conditions favorable or not) the upper tropospheric ozone column or the entire tropospheric column can be slightly contaminated by the stratospheric contribution. More precisely the averaging kernels corresponding to the altitude of the upper troposphere are not zero in the lower stratosphere. A small stratospheric contribution can then be integrated in the upper tropospheric ozone retrieved. In the following sections, we therefore essentially focus on the lower tropospheric columns from the surface to $6 \mathrm{~km}$. We have chosen this upper limit for the columns not only because it fits the ozone operational product distributed by Eumetsat but mainly because the potential stratospheric contribution on the $0-6 \mathrm{~km}$ column is limited: the averaging kernels for the altitude up to $6 \mathrm{~km}$ fall down to 0 or are negligible at the tropopause level (Fig. 2).

In order to illustrate the ability to separate different partial columns from the lower troposphere to the lower stratosphere, we have plotted the monthly variations of different
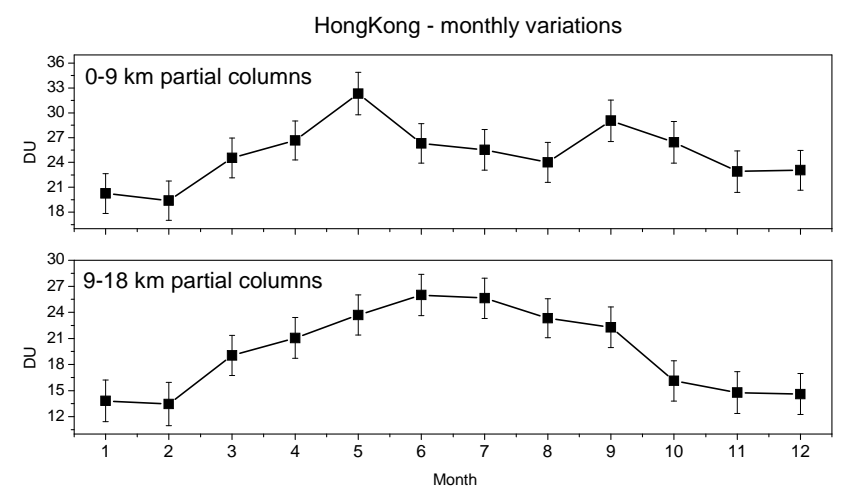

Fig. 5. Monthly mean variations of different partial columns (0$9 \mathrm{~km}$ column, and $9-18 \mathrm{~km}$ column) retrieved from IASI observations over Hong Kong in 2008.

partial columns in Figs. 3, 4 and 5 (The choice of the partial columns is based on the examination of the averaging kernels especially during spring and summer when the thermal conditions are more favorable for an effective separation). Three partial columns are displayed for Beijing: 0-6 km, 6$12 \mathrm{~km}$ and $12-18 \mathrm{~km}$ (Fig. 3). During winter the $0-6 \mathrm{~km}$ partial columns and the 6-12 km partial columns show similar variations and cannot be well separated. On the contrary, the variations observed from April to September are different for the three partial columns. However during the last three months of the year the increase of the column amount for the $6-12 \mathrm{~km}$ partial column is certainly correlated to the increase observed in the $12-18 \mathrm{~km}$ partial column. Similar behaviors can be observed for Shanghai (Fig. 4) and Hong Kong (Fig. 5) showing that the lower and the upper tropospheric ozone can be separated by the IASI observations from April to October for the three areas.

\section{Seasonal variations of tropospheric ozone over Bei- jing, Shanghai, and Hong Kong}

Ozone in the troposphere presents an annual cycle that varies as a function of the geolocation (Monks, 2000; Logan, 1999; Vingarzan, 2004). Monks (2000) reports in a detailed review that surface ozone exhibits a spring maximum at coastal sites of Northern Europe whereas continental sites and highaltitude mountain sites show a broad summer maximum. Zbinden et al. (2006) report on climatological measurements made within the MOZAIC framework (Marenco et al., 1998) and show that tropospheric ozone presents a broad summer maximum over different European and North American cities. This broad summer maximum is mainly attributed to photochemical production. In East Asia, the seasonal variations of surface and tropospheric ozone are not driven by the same processes especially during the summer monsoon. Several studies report on these seasonal variations at different locations of Eastern China and Japan (e.g. Chan et al., 1998; 
Naja and Akimoto, 2004; Kim et al., 2006; Li et al., 2007; Ding et al., 2008; He et al., 2008). They show a sharp maximum in late spring and a minimum during summer (July, August especially). The timing of the sharp maximum varies with longitude and altitude (Kim et al., 2006). Different processes can contribute to this maximum. A first hypothesis is the accumulation of ozone precursors during winter that are processed when radiation and temperature increase, coupled with an increase of photochemical production (Penkett and Brice, 1986; Penkett et al., 1993). Another process that can also contribute is the stratospheric-tropospheric exchange that can bring ozone-rich air from the stratosphere down to the free troposphere and the surface (Monks, 2000). In East China, biomass burning can also play a significant role in the increase of ozone and precursors in late spring and early summer (e.g. Liu et al., 1999; Pochanart et al., 2003). The key mechanism that contributes to the summer minimum is the intrusion of low-ozone marine air masses coming from the tropical Pacific (e.g. Lin et al., 2009). Actually, the flow direction becomes more southerly during the Asian summer monsoon bringing clean air masses from the Pacific (e.g. Ding et al., 2008; Liu et al; 2002). The influence of the summer monsoon is more pronounced in the South than in the North of China. A second maximum in fall is reported for measurements performed in Southern China, in the area of Hong Kong (Chan et al., 1998).

In this section, we present the monthly averaged tropospheric ozone (partial columns) for 2008 over the three regions considered: Beijing, Shanghai, and Hong Kong. Due to the decrease of the IASI coverage when going to the equator (consecutive swaths do not overlap below $40^{\circ} \mathrm{N}$ ) and due to the increase of cloud cover during the monsoon period, a satisfactory daily coverage for the considered area is difficult to achieve especially in summer as shown by the percentages of cloud free and quality flagged columns considered for each city per month (Fig. 6). We then chose to calculate a global monthly average including all the data for each month without any pooling per day. We checked also that the monthly spatial coverage of the data was sufficiently homogeneous over each of the considered regions.

In Fig. 7, the monthly variations of the $0-6 \mathrm{~km}$ ozone column are compared to the climatological monthly variations for the corresponding latitude bands calculated from the McPeters et al. (2007) climatology. The climatological variabilities attached to each climatological monthly mean are also plotted in Fig. 7. The latitude bands chosen for the comparison were selected according to the backtrajectories calculations and correspond to the latitudes from where the air masses mainly come from (Figs. S1-S3, http://www.atmos-chem-phys.net/10/ 3787/2010/acp-10-3787-2010-supplement.pdf). Note that the climatological partial columns considered here are zonal partial columns. They then include longitudes outside Asia. Then, the climatological columns do not especially reflect the Asian monsoon influence contrary to the IASI observations.

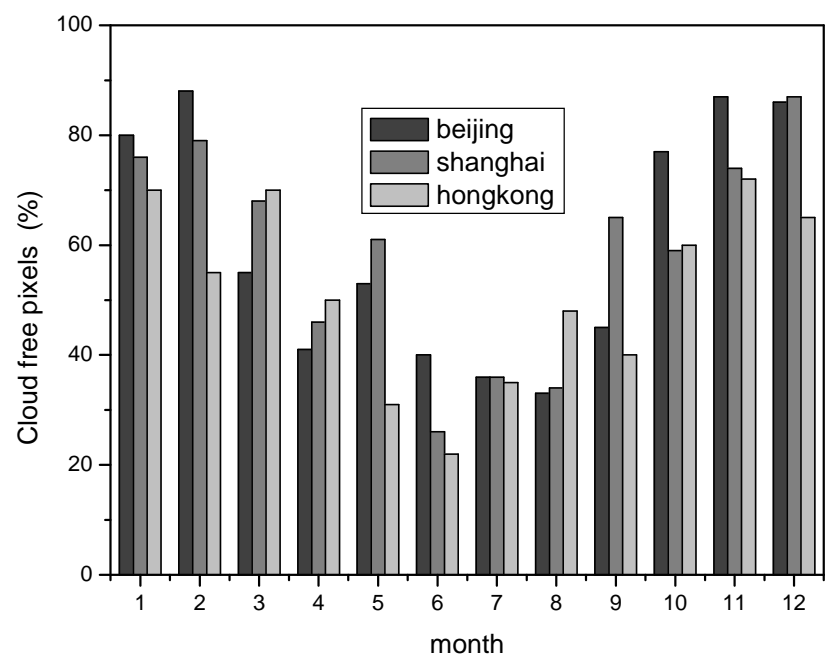

Fig. 6. Percentage of cloud free and ozone quality flagged IASI pixels per month for the 3 regions for the year 2008 .

\subsection{Beijing area}

Previous studies report on the influence of the Asian summer monsoon up to Northern China, Korea and Japan (e.g. Ding et al., 2008; Naja and Akimoto, 2004; Kim et al., 2006). Ding et al. (2008) present a climatology of tropospheric ozone over Beijing based on aircraft data from the MOZAIC program. They show that the influence of the summer monsoon is more pronounced in the lowest layers of the troposphere with a sharp decrease in July for the layer between the surface and $600 \mathrm{~m}$ (note that IASI is not very sensitive to the ozone surface layer, Fig. 2). The maximum broadens for higher altitudes and the decrease is smoothed. The sharp maximum in May-June at the surface level is replaced by a broad summer maximum between 4 and $8 \mathrm{~km}$ (see Fig. 4 in Ding et al., 2008). The monthly mean 0$6 \mathrm{~km}$ partial columns of ozone observed by IASI in 2008 over Beijing $\left(39.90^{\circ} \mathrm{N}, 116.39^{\circ} \mathrm{E}\right)$ are shown in the top panel of Fig. 7. The IASI observations show a maximum in May followed by a smooth decrease to finally reach a minimum in early winter. This smooth decrease (Fig. 7) is consistent with the MOZAIC climatology with a smooth decrease starting in June (Ding et al., 2008). On the contrary, the climatological ozone columns show a broader summer maximum. The difference between the duration of the summer maximum of the climatology and of the IASI measurement over Beijing illustrates the impact of the Asian summer monsoon in the Beijing area. Indeed, the flow of clean air imported from the Pacific reduces the ozone level during summer in the lower troposphere. The Pacific origin of the air masses is illustrated by the backtrajectories plots provided in the supplementary material (Fig. S1, http://www.atmos-chem-phys.net/10/ 3787/2010/acp-10-3787-2010-supplement.pdf). Moreover, the differences between the $0-6 \mathrm{~km}$ columns measured from IASI and those from the climatology peak at $2.7 \mathrm{DU}$ at the 

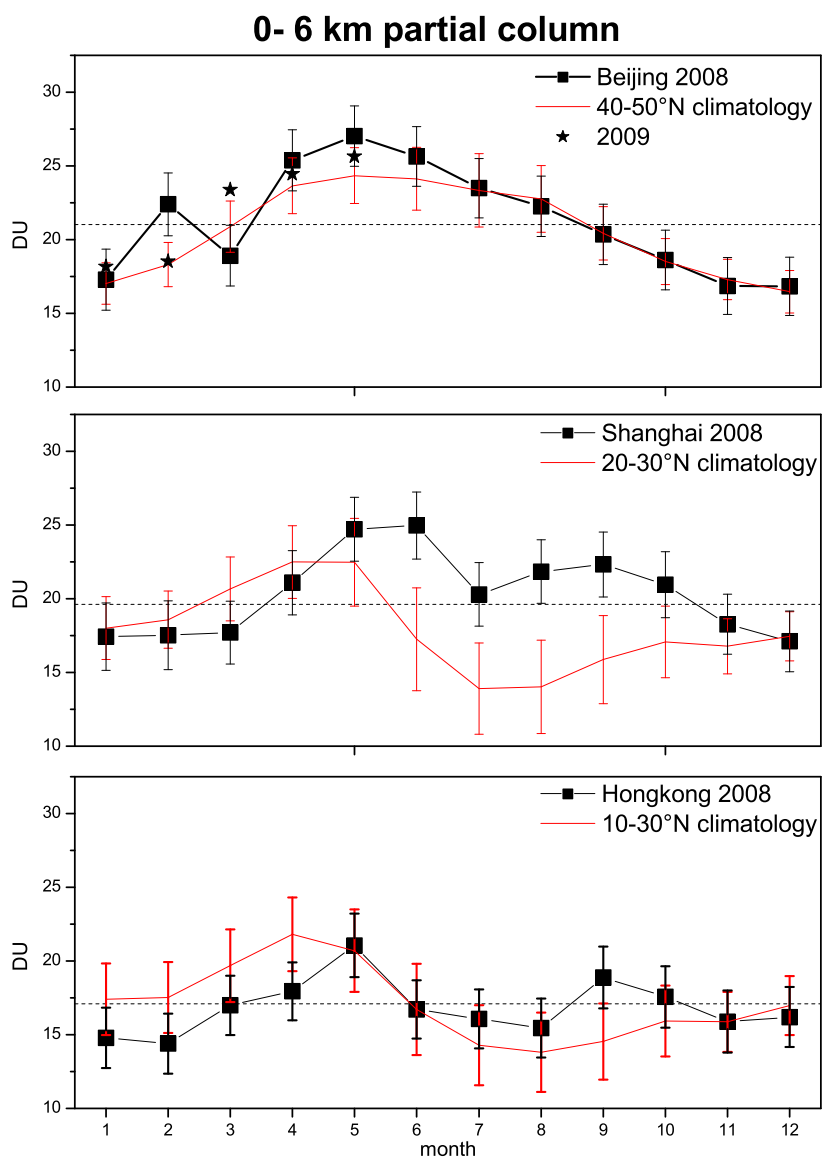

Fig. 7. Monthly variations of the mean $0-6 \mathrm{~km}$ ozone columns measured with IASI in 2008 over Beijing (top), Shanghai (middle), and Hong Kong (bottom), in Dobson Unit (DU). The mean columns are compared to the climatological column values (McPeters et al., 2007) for the latitudes bands that mostly influence each domain (red). The climatological variability is plotted as error bars for the climatological columns. The black stars in the top panel correspond to the monthly mean columns observed in 2009 over Beijing. The errors on the IASI observations are estimated for individual columns and for the typical conditions of each month.

maximum in May, the columns over Beijing being larger than the climatology. If one compares the difference between the total error on the column (2.05 DU in May) and the climatological variability $(1.89 \mathrm{DU})$, ones sees that the difference is marginally significant. Note that the examination of the ozone concentration retrieved at $3 \mathrm{~km}$ (the maximum of the averaging kernels in spring-summer) (not shown here) reveals that the ozone concentration is up to $10 \mathrm{ppbv}$ larger over Beijing during the April-to-July period than the values given by the climatology that is more representative of background ozone. The largest value observed with IASI over Beijing at $3 \mathrm{~km}$ is about $70 \mathrm{ppbv}$ and is in agreement with the values derived from the MOZAIC measurements above Beijing (Ding et al., 2008). The enhancement of ozone compared to the climatology over Beijing would then possibly suggest that highly polluted air masses (anthropogenic and/or biomass burning sources) are sounded during this period.

As already mentioned in Sect. 2.2, different partial columns can be separated from the IASI measurements during the favorable seasons of spring and summer. Figure 3 shows the monthly variations of the $0-6 \mathrm{~km}, 6-12 \mathrm{~km}$ and $12-18 \mathrm{~km}$ partial ozone columns over Beijing. The maximum of ozone is shifted from May to June between the 0$6 \mathrm{~km}$ and 6-12 km columns. Kim et al. (2006) has already reported a similar one-month delay in the seasonal cycle between the lowest layers of the troposphere and the free/upper troposphere. They related this one-month delay to the time needed for the transport between the different parts of the troposphere. However, in the case of IASI, the complete significance of the one-month delay observed is partly questionable due to the errors on the observations.

Large tropospheric ozone columns are observed in February 2008 compared to January 2008 and March 2008 and to the climatology (Fig. 7). The monthly mean for the beginning of 2009 are added in Fig.7 (stars) for comparison and do not exhibit a similar enhancement in February. Possible explanations for the enhanced 0-6 km columns observed in February 2008 are: (i) a lower tropopause (about $9 \mathrm{~km}$ against $10 \mathrm{~km}$ and higher in January and March) leading to a larger contamination of the $0-6 \mathrm{~km}$ columns by the stratospheric ozone (see Sect. 2.2); (ii) a descent/intrusion of stratospheric air rich in ozone (see Sect. 4). Note also that the difference between the mean columns observed in March 2008 and March 2009 are certainly not related to different geophysical conditions between the two years but more certainly arises from a sampling issue of IASI. In March 2008, observations were made only during the first half of March, due to an ice decontamination period, whereas the 2009 observations were made during the whole month of March 2009.

Figure 8 shows the monthly mean $0-6 \mathrm{~km}$ columns of ozone, resolved in space, in the region of Beijing. The seasonal cycle is also well visible with a maximum in May but with additional information on the spatial distribution of ozone in the area. The largest ozone columns are observed in May over the northern part of the North China Plain and are located in the vicinity of the most populated parts of the region as expected. Comparison with the population density map shows a good consistency between the most populated area and the large ozone columns except for the southern part of the subdomain (Fig. 9, black square). This can be explained with the analysis of the mean winds from ECMWF (Fig. 9b). The analysis shows that the air masses are coming from the South where the population density is high again (Fig. 9) and from the South-East where fires occurs during this month. On the contrary it is worth noticing that the ozone distribution during the winter months is rather uniform. During this period, the observations are mainly sensitive to the free and the upper troposphere (Sect. 2.2) where and when the variability of ozone on small spatial scale is rather weak. 


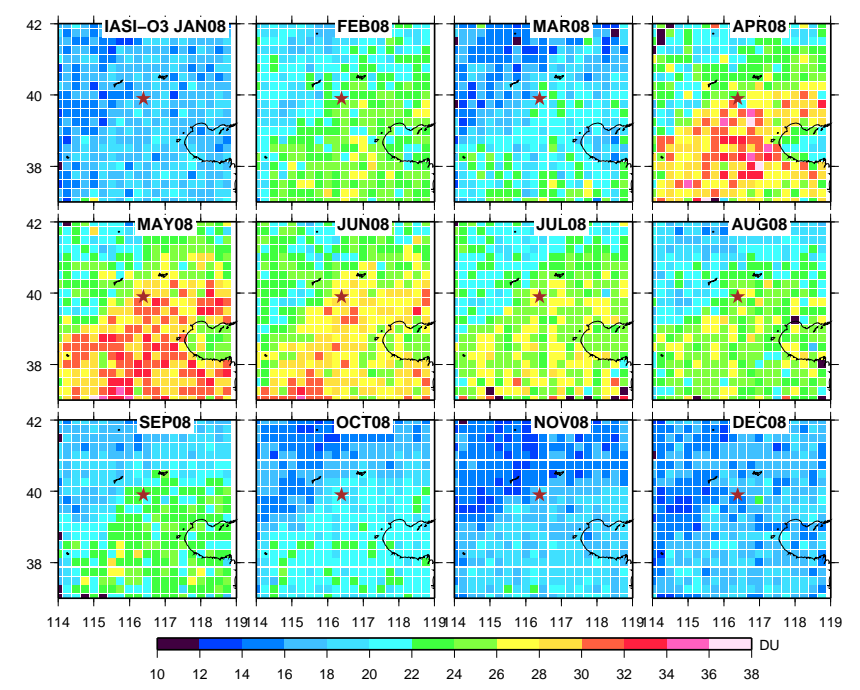

Fig. 8. Monthly mean $0-6 \mathrm{~km}$ ozone columns from IASI spatially averaged on a $0.25^{\circ} \times 0.25^{\circ}$ latitude-longitude grid for 2008 in the Beijing region (given in Dobson Unit, DU). Beijing location is indicated by a brown star. Black squares when no data is available in the grid cell.

As mentioned previously, the explanation of these large ozone columns is a combination of several processes: photochemical production from local anthropogenic sources but also from biomass burning sources, activation of precursors accumulated during winter, and stratospheric-tropospheric exchange. Dedicated model studies will be necessary to identify the relative contribution of each process.

\subsection{Shanghai area}

The monthly mean $0-6 \mathrm{~km}$ columns of ozone over the Shanghai area $\left(31.13^{\circ} \mathrm{N}, 121.27^{\circ} \mathrm{E}\right)$ are reported in the middle panel of Fig. 7. An analysis of the backtrajectories calculated over the year shows that air masses come mainly from the South from April to October (Fig. S2, http://www.atmos-chem-phys.net/10/3787/2010/ acp-10-3787-2010-supplement.pdf). Moreover, we checked that the climatological ozone values of the $20-30^{\circ} \mathrm{N}$ and 30 $40^{\circ} \mathrm{N}$ latitude bands are similar during winter. For these reasons, we chose to compare the ozone seasonal cycle derived from IASI with the climatological ozone columns for the 20$30^{\circ} \mathrm{N}$ latitude band. A seasonal cycle with a maximum in May-June is observed but, contrary to Beijing, a sharp drop of the $0-6 \mathrm{~km}$ ozone columns occurs in July. A secondary maximum is observed in fall (September-October). The seasonal cycle observed from IASI data is in fair agreement with the climatological variations reported for the $20-30^{\circ} \mathrm{N}$ latitude band, except that the maximum is observed one month later in 2008 with IASI. The balloon sonde stations used by McPeters et al. (2007) for the climatology of the $20-30^{\circ} \mathrm{N}$ latitude band include two Japanese stations among the three

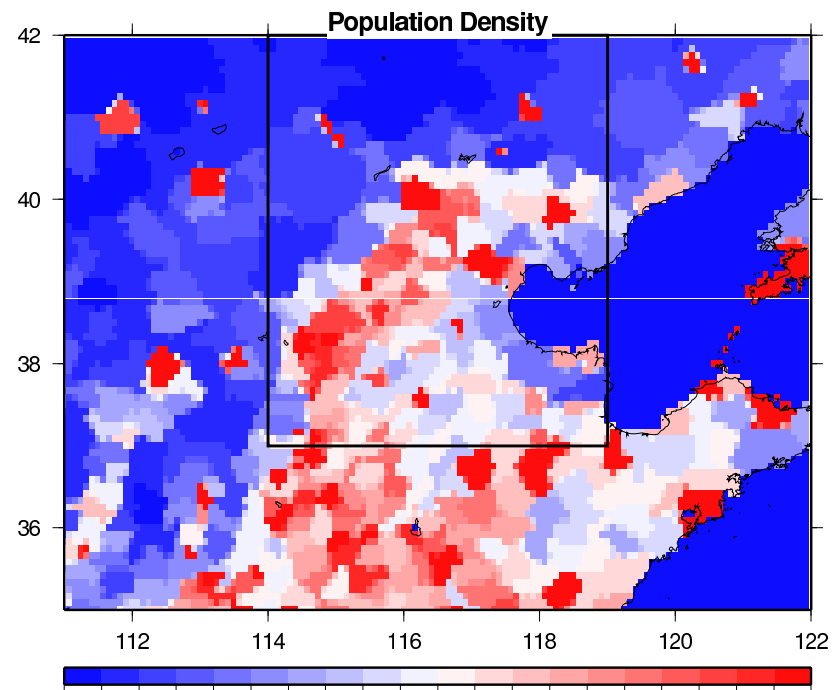

0501001502002503003504004505005506006507007508008509009501000

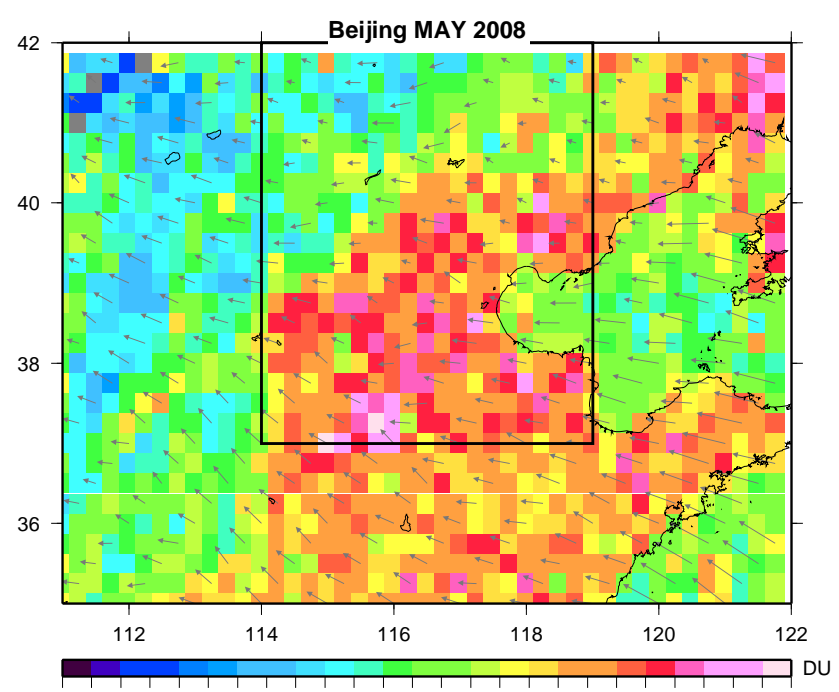

1112131415161718192021222324252627282930313233343536

Fig. 9. (a) Population density (in persons per $\mathrm{km}^{2}$ ) in North China. The Beijing area considered in this study is represented by the black square. (b) Monthly wind field at the surface from ECMWF meteorological forecasts. The mean $0-6 \mathrm{~km}$ ozone columns measured during May 2008 are also plotted.

stations considered. These two stations certainly strongly suffer from the Asian monsoon influence during summer: the climatology for this latitude band is then partly representative of the monsoon effect on ozone concentrations. Kim et al. (2006) reports on the seasonal cycles of ozone for different altitudes in Korea for latitudes close to those of Shanghai and show that a sharp drop of ozone concentrations occur in July between 1 and $5 \mathrm{~km}$ (see Fig. 2 in Kim et al., 2006) as shown by the IASI observations for the Shanghai region. This sharp drop is attributed to the summer monsoon that brings clean air from the tropical Pacific. Kim et al. (2006) 


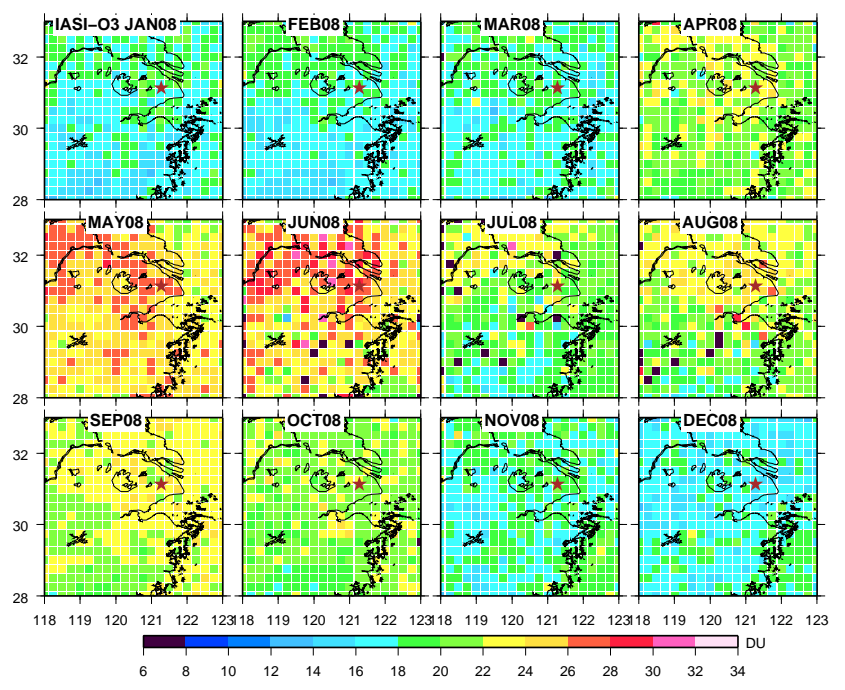

Fig. 10. Same as Fig. 8 for Shanghai.

describe also a shift in the timing of the ozone maximum between Korea and Japan, with the ozone maximum in Japan occurring one month earlier. This strongly suggests that the shift observed between the IASI observations over Shanghai and the $20-30^{\circ} \mathrm{N}$ latitude band climatology (mainly based on Japanese sites) is true.

On the other hand, the difference between the $0-6 \mathrm{~km}$ columns above Shanghai and the climatological columns is about 2.5 DU at the late spring summer maximum and reach 6.4 DU in September during the second maximum. If the difference at the primary maximum is only slightly significant compared to the errors in the observations (2.2 DU) and to the climatological variability (3DU), the difference at the second maximum in September is significant. According to the backtrajectory calculations, the origin of the large ozone amount in fall cannot be due to a transport of ozone-rich air from higher altitudes. The air masses at $3 \mathrm{~km}$ over Shanghai come from lower altitudes (Fig. S2, http://www.atmos-chem-phys.net/10/3787/ 2010/acp-10-3787-2010-supplement.pdf) during this period (August to October). Accordingly a more likely explanation is that air masses observed by IASI over Shanghai are affected by local enhanced photochemical production due to pollution (and/or biomass burning). This then suggests an anthropogenic origin of the second maximum observed over Shanghai in early fall. An anthropogenic origin for a similar second maximum in Hong Kong region has already been reported (Liu et al., 2002). The previous discussion is relevant since, as mentioned in Sect. 2.2, the lower and upper tropospheric columns can be well separated from the observations in particular during spring and summer (Fig. 4). Opposite to the lower tropospheric column, the upper tropospheric column does not exhibit any drop during summer or any secondary maximum in fall.
The monthly mean spatial distribution of the $0-6 \mathrm{~km}$ ozone columns measured with IASI is displayed in Fig. 10. The June maximum shown in Fig. 7 is also well visible in Fig. 10 with the maxima mainly located along the Yangtze River where the density of population is the largest one. As for Beijing region, the ozone distribution during winter months is rather uniform and also reflects the free and the upper tropospheric ozone (Sect. 2.2), less variable at this spatial scale.

\subsection{Hong Kong area}

The monthly mean $0-6 \mathrm{~km}$ columns of ozone over the Hong Kong area $\left(22.25^{\circ} \mathrm{N}, 114.17^{\circ} \mathrm{E}\right)$ are reported in the bottom panel of Fig. 7 and compared to the corresponding climatology of the $10-30^{\circ} \mathrm{N}$ latitude band. The seasonal cycle of ozone as shown by the IASI columns exhibits one maximum in May and a second significant maximum in SeptemberOctober. The agreement with the climatological column values is rather good but with smaller IASI columns during winter (January to April). The $0-6 \mathrm{~km}$ columns over Hong Kong and from the climatology are in good agreement at the ozone maximum in May but also during the summer minimum. Concerning the second ozone maximum observed with IASI in fall, the observations over Hong Kong are significantly larger (4.4 DU) as compared to the errors in the observations $(2.1 \mathrm{DU})$ and the climatological variability $(2.6 \mathrm{DU})$. These large values are consistent with the results of several studies based on time series performed at a surface site or with ozone sonde measurements close to Hong Kong which report also such a maximum in fall (Chan et al., 1998; Lam et al., 2001; Wang et al., 2009). This fall maximum which occurs mainly in the two lowest kilometres (Chan et al., 1998) is attributed to a photochemical production due to pollution (Liu et al., 2002). This is visible in the IASI retrieved columns (Fig. 7) which are significantly larger than those of the climatology for this period. The discussion above is relevant since, as mentioned in Sect. 2.2, the lower and upper tropospheric partial columns can be discriminated from the IASI observations over Hong Kong (Fig. 5): The two maxima observed in the lower tropospheric columns are not visible in the upper tropospheric columns, the seasonal variation of the upper tropospheric column showing only a broad summer maximum.

The monthly mean spatial distribution of the $0-6 \mathrm{~km}$ ozone columns measured with IASI is displayed in Fig. 11. The late spring maximum is well visible with the largest ozone columns in the vicinity of the main cities of the area. The maximum in fall is especially visible in September and the largest ozone columns are also close to the main cities, suggesting a photochemical production. As for Beijing and Shanghai regions, the ozone distribution during winter months is rather uniform. The observations are mainly sensitive to the free troposphere in this case (Sect. 2.2) and the uniform distribution of ozone reflects the free tropospheric ozone that presents less variability at this scale, especially in the tropics. 


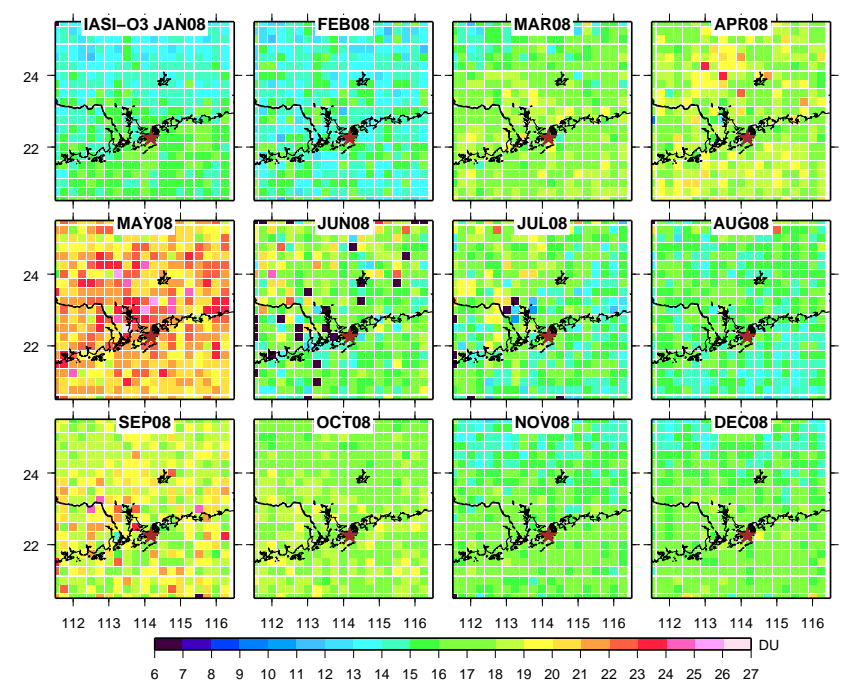

Fig. 11. Same as Fig. 8 for Hong Kong.

\section{Day to day variation of tropospheric ozone over Beijing}

In the previous section, we have shown that, using IASI measurements, it is possible to derive seasonal variations of tropospheric ozone representative of the lower troposphere. In this section, we investigate the possibility of retrieving the day-to-day variation of tropospheric ozone focusing on the Beijing area (We recall that only the morning overpasses are considered).

The upper panel of Fig. 12 shows the $0-6 \mathrm{~km}$ ozone columns averaged over Beijing for each day of February (morning overpasses). The bottom part of these figures shows the spatial distribution of the columns for 4 selected days (red circles) during which events of large tropospheric ozone amounts are detected with IASI. The analysis of the profiles retrieved for the 4-days period and averaged over the Beijing domain (Fig. 13) shows large ozone values in the stratosphere and low ozone values in the troposphere on 7 February. This changes to large ozone values in both troposphere and stratosphere on 8 February and is followed by lower values in both the troposphere and the stratosphere on 9 and 10 February. One hypothesis to explain the large ozone amounts observed on 8 February, suggested by the analysis of the profiles, is that the $0-6 \mathrm{~km}$ column is influenced by stratospheric ozone rich air masses either because of a low tropopause or/and because of stratospheric intrusion. To test this hypothesis, we calculate the mean tropopause height based on NCEP meteorological fields. The tropopause heights on 7 and 8 February and are $7.8 \mathrm{~km}$ and $8.1 \mathrm{~km}$ respectively, whereas the tropopause is higher on the two following days, about $9.5 \mathrm{~km}$. As mentioned in Sect. 2.2, the averaging kernels during winter in Beijing are broad and have a maximum around $7 \mathrm{~km}$ close to the tropopause. The $0-6 \mathrm{~km}$ columns measured on 7 and 8 February are then likely more
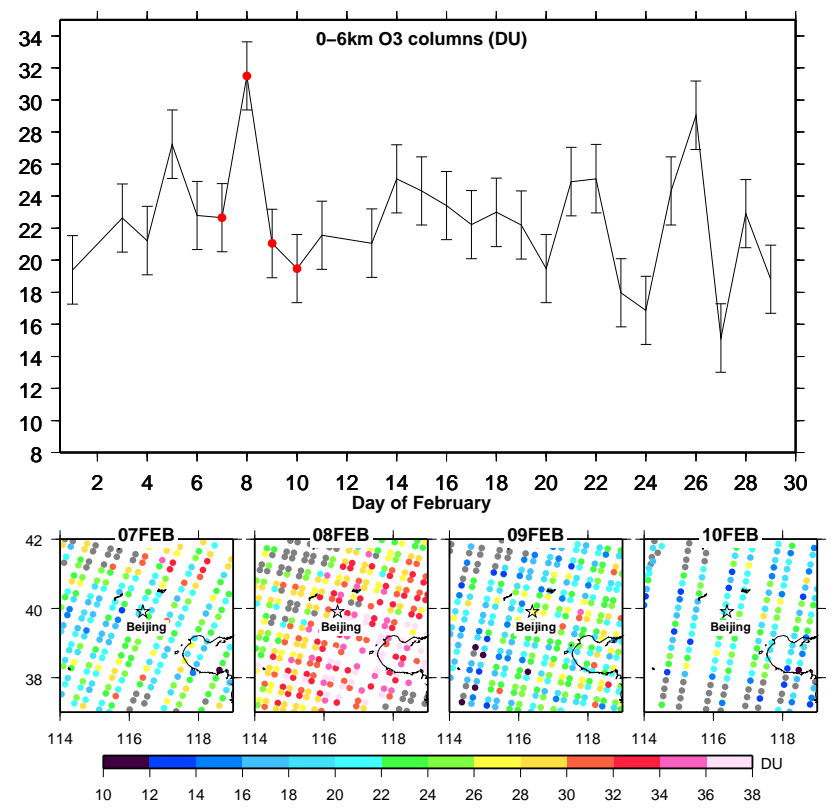

Fig. 12. 0-6 km ozone columns (morning pass) retrieved from IASI over the Beijing region and averaged over the domain as a function of day (top). The corresponding spatial distribution of the partial columns for 4 selected days from 7 to 10 February, marked with red dots in the upper panel, is plotted in the bottom. Each circle corresponds to one IASI pixel. Grey circles represent cloudy pixels.

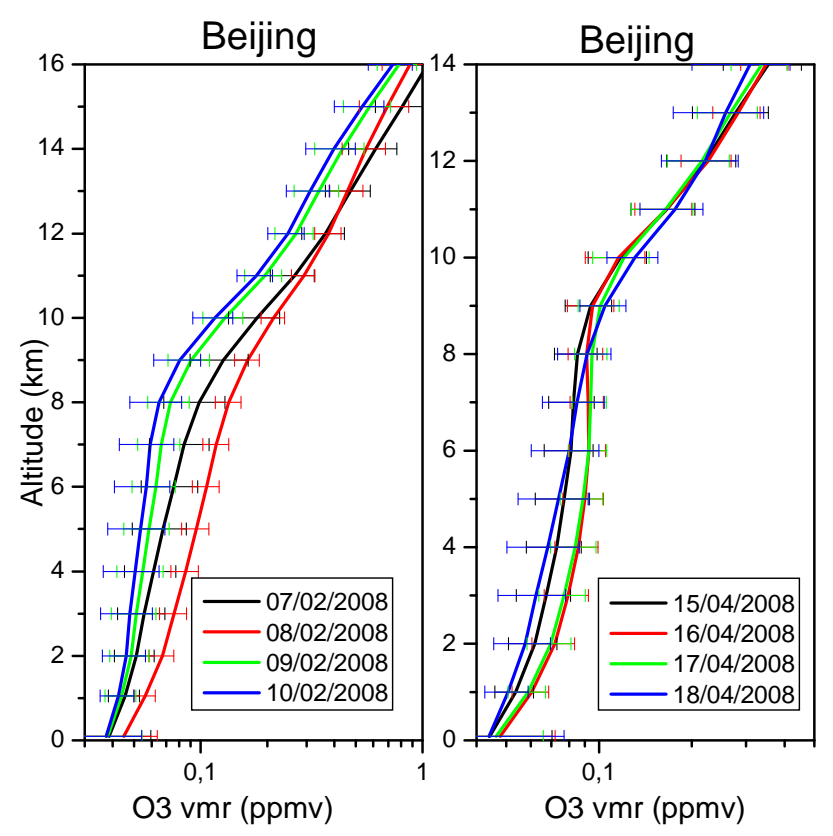

Fig. 13. Ozone profiles retrieved from IASI for the two selected periods with enhanced ozone events over Beijing. The ozone profiles retrieved for the morning overpasses are averaged over the Beijing area. The error bars corresponds to the standard deviation of the mean. 


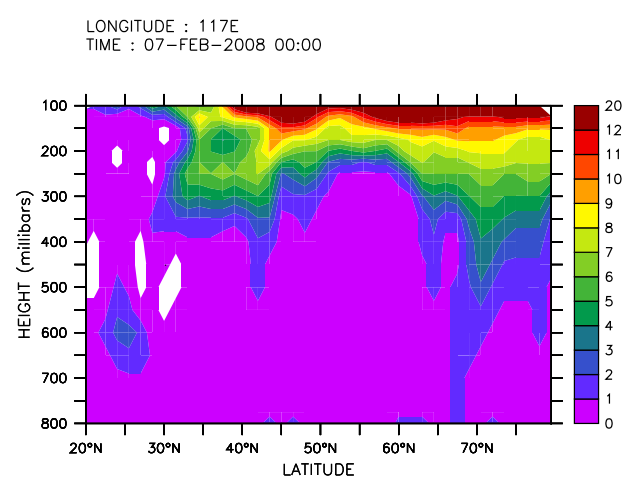

ERAint PV

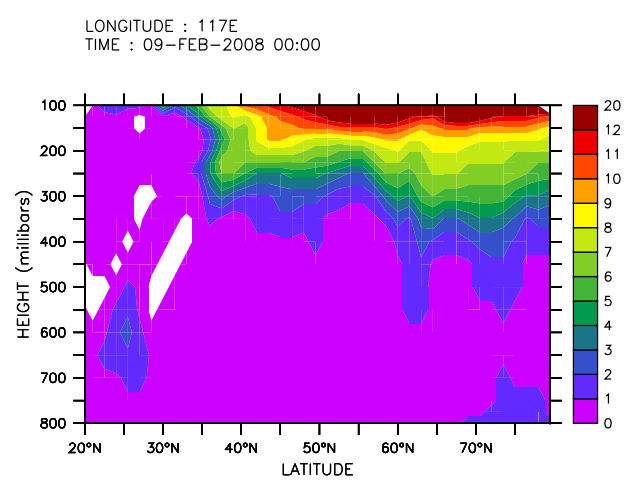

ERAint PV
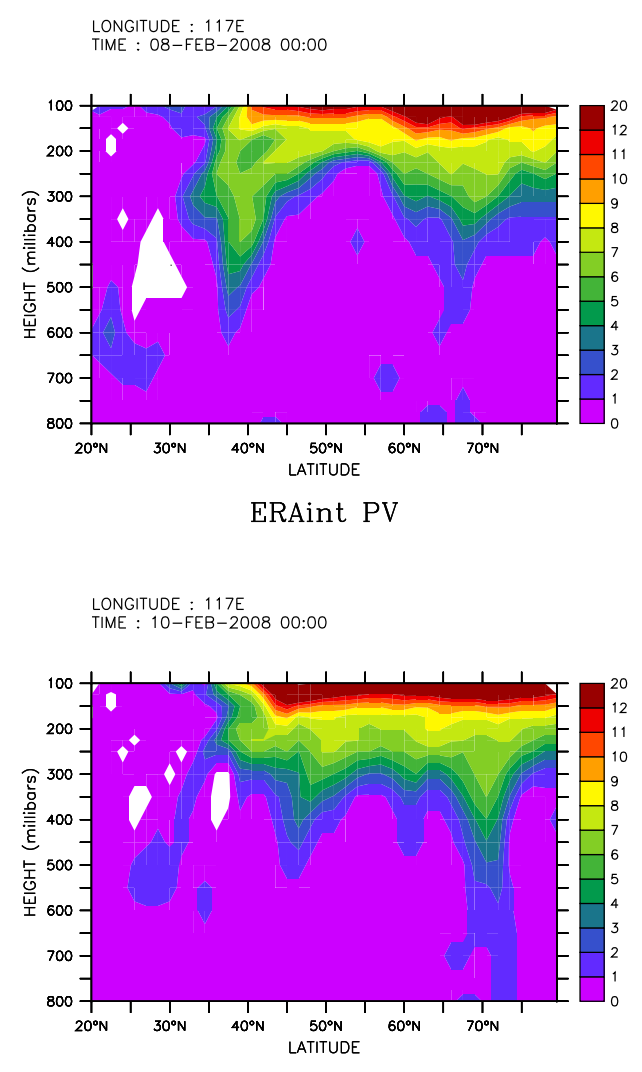

ERAint PV

Fig. 14. Cross-sections of PV against latitude at $117^{\circ} \mathrm{E}$ longitude from 7 to 10 February taken from ECMWF ERA interim database.
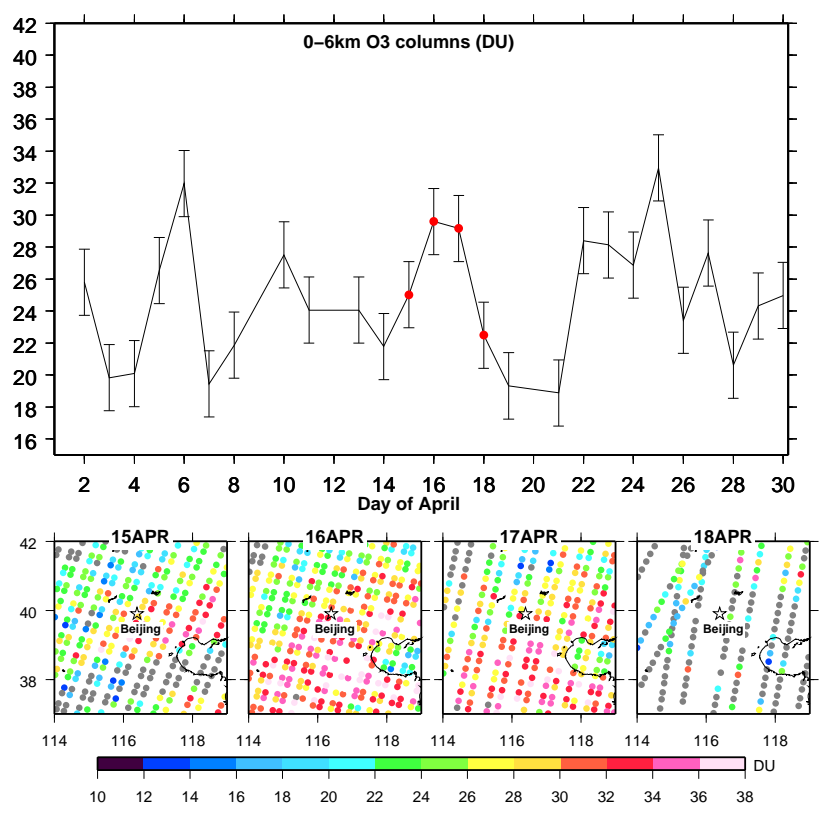

Fig. 15. Same as Fig. 12 for the period from 15 to 18 April. affected by a stratospheric contribution than those measured on 9 and 10 February. Moreover, the cross-sections of PV against latitude taken at $117^{\circ} \mathrm{E}$ longitude show a large intrusion of stratospheric down to $550 \mathrm{hPa}$ on 8 February around $40^{\circ} \mathrm{N}$, the latitude of Beijing (Fig. 14). This is fully consistent with the interpretation given from the analysis of the IASI profiles (Fig. 13).

Figure 15 shows the $0-6 \mathrm{~km}$ ozone columns averaged over Beijing for each day of April. The bottom parts of the figure show the spatial distribution of the columns for 4 selected days (red circles) during which events of large tropospheric ozone amounts are detected with IASI. The situation is different as compared to February: the stratospheric ozone values are similar for the 4 days (Fig. 13). Only the tropospheric part of the ozone profiles is enhanced on 16 and 17 April, suggesting that the large ozone tropospheric amounts are from tropospheric origin: pollution with enhanced photochemical production, biomass burning, etc. In order to evaluate if the anthropogenic origin of the large ozone amounts observed on 16 and 17 April is plausible, we analyzed the surface winds as well as the $3 \mathrm{~km}$ winds extracted from the meteorological field forecasted by ECMWF. Figure 16 shows the $0-6 \mathrm{~km}$ ozone columns observed over Beijing and the associated winds at the surface and at $3 \mathrm{~km}$ for 17 April and 


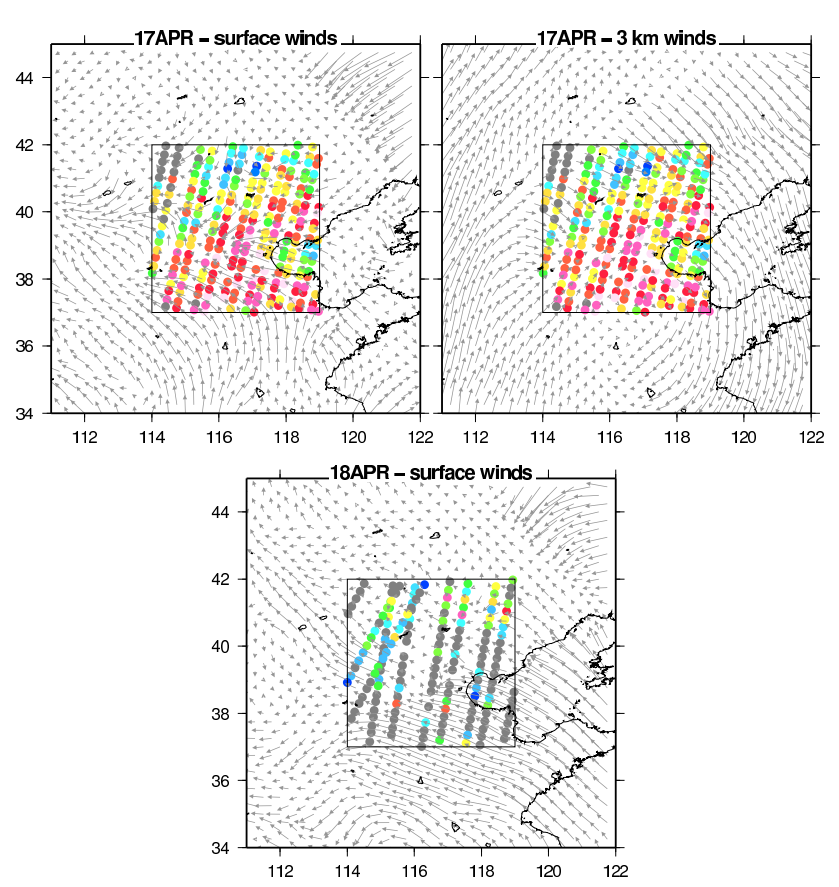

Fig. 16. Wind fields from ECMWF meteorological forecasts at the surface or at $3 \mathrm{~km}$ over North China for 17 and 18 April. The 0-6 km ozone columns measured for each individual pixel of the morning overpass over Beijing are also plotted (grey circles represent cloudy pixels).

at the surface for 18 April. On 17 April, the air masses that reach the southern half of the Beijing area come from the South (Fig. 16) and have passed through highly populated regions lying more southerly than the considered domain for Beijing (Fig. 9a). Closer to the Beijing city centre, the large ozone columns more likely reflect local production in the Beijing district itself (Fig. 16). Surface winds suggest indeed a transport to the South-West direction of the district. It is worth noting that the wind field at $3 \mathrm{~km}$ (the maximum of the ozone profiles averaging kernels) on 17 April suggests more stagnant air masses, favorable for ozone enhancement. On 18 April, the surface winds change: they are stronger and come from the Pacific. The meteorological situation has changed and this is consistent with the larger number of cloudy pixels detected during this last day of the period. Another point that supports the anthropogenic origin of the large ozone event is the Air Pollution Index (API) given for Beijing during this period (Fig. 17). The API is a combination of 5 pollutants $\left(\mathrm{NO}_{2}, \mathrm{CO}, \mathrm{O}_{3}, \mathrm{SO}_{2}\right.$, and PM10). Figure 17 shows that the API exceeds the threshold of 100 for which the air is considered to be harmful for human beings from 15 April and starts to decrease on 18 April.

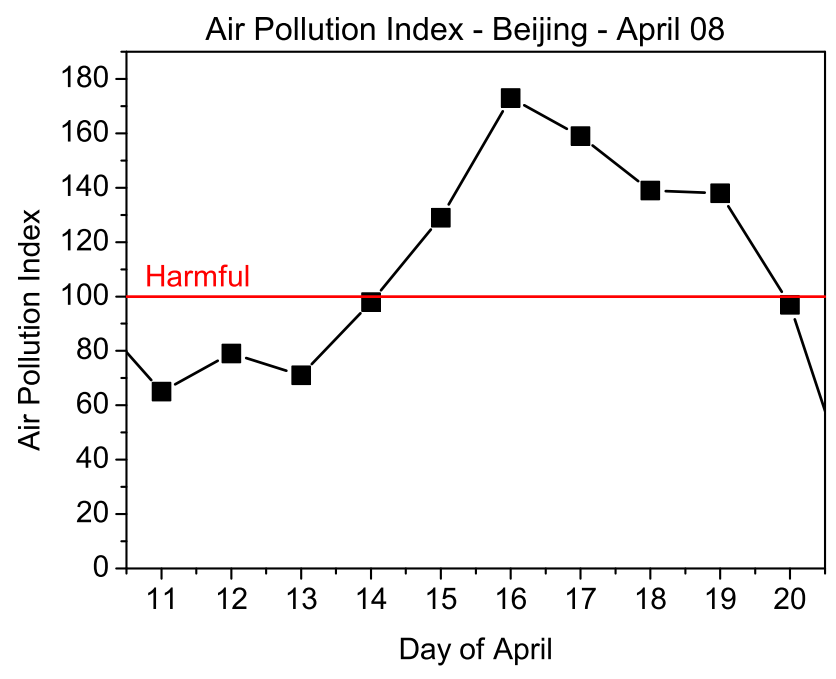

Fig. 17. Air Pollution Index (API) recorded in Beijing from 11 to 20 April (http://english.sepa.gov.cn/).

\section{Conclusion}

In this paper we have studied one year of IASI observations of tropospheric ozone over three Chinese highly populated areas $\left(5^{\circ} \times 5^{\circ}\right.$ in latitude and longitude around each city). The monthly mean variations of lower tropospheric ozone measured with IASI (partial columns) show the influence of the summer Asian monsoon on the ozone concentrations in the lower troposphere with a sharp maximum in late spring and early summer (May-June) followed by a decrease during summer. The intensity of this decrease depends on the latitude: the drop is sharper for the tropical latitudes (Hong Kong and Shanghai) than for the midlatitudes (Beijing).

Larger monthly ozone values are observed in spring/summer (April to June) in the Beijing area and in early fall (September-October) in the Shanghai and Hong Kong areas. It is interesting to note that the differences between the retrieved and the climatological ozone values remain rather significant when compared to the measurement errors and the climatological variabilities. Moreover, one can note that a validation study (Keim et al., 2009) does not reveal any systematic bias in the IASI retrievals $(<5 \%)$. One hypothesis to explain the larger ozone amounts observed with IASI above the three highly populated areas of China is the enhanced photochemical production of ozone due to pollution events or biomass burning. This hypothesis is supported by comparisons of the ozone distribution with the population density and by the analyses of the meteorological winds.

The spatial and temporal coverage of IASI observations allowed us to follow the daily variations (spatially resolved) of ozone. Selected time periods with enhanced ozone detected with IASI over Beijing region have been analysed. We show that the large ozone amount observed in the lower 
troposphere during winter has a stratospheric origin. On the contrary, the large ozone amounts observed in the lower troposphere in spring and summer are more probably related to an enhanced photochemical production of ozone linked to anthropogenic origins (pollution or biomass burning).

Finally, the results presented in this paper demonstrate the ability to discriminate, using the IASI measurements, between the different behaviours of the lower and the upper troposphere despite a limited number of degrees of freedom in the troposphere (up to 1.5).

Acknowledgements. The authors are grateful to CNRS-INSU for publication support. We thank the Institut für Meteorologie und Klimaforschung (IMK), Karlsruhe Institute of Technology (KIT), Germany, for a licence to use the KOPRA radiative transfer model, and especially M. Höpfner for his help to set up the code. We thank Peter Hoor for his help with the PV map. We thank the ETHER database (CNRS, INSU, CNES) in France for providing access to IASI Level 1 data. This study was supported by the French Space Agency CNES (project "IASI-TOSCA"). The authors gratefully acknowledge the NOAA Air Resources Laboratory (ARL) for the provision of the HYSPLIT transport and dispersion model and/or READY website (http://www.arl.noaa.gov/ready.html) used in this publication. NCEP Reanalysis data provided by the NOAA/OAR/ESRL PSD, Boulder, Colorado, USA, from their Web site at http://www.cdc.noaa.gov. We acknowledge ECMWF for the access to the meteorological data.

Edited by: M. Van Roozendael

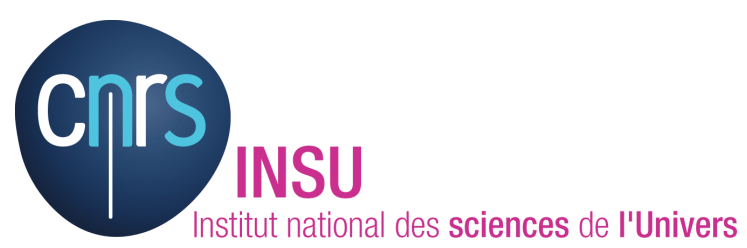

The publication of this article is financed by CNRS-INSU.

\section{References}

Akimoto, H.: Global air quality and pollution, Science, 302, 17161719, 2003.

Boynard, A. Clerbaux, C., Coheur, P.-F., Hurtmans, D., Turquety, S., George, M., Hadji-Lazaro, J., Keim, C., and Meyer-Arnek, J.: Measurements of total and tropospheric ozone from IASI: comparison with correlative satellite, ground-based and ozonesonde observations, Atmos. Chem. Phys., 9, 6255-6271, 2009, http://www.atmos-chem-phys.net/9/6255/2009/.

Chan, L. Y., Liu, HH. Y., Lam, K. S., Wang, T., Oltmans, S. J., and Harris, J. M.: Analysis of the seasonal behaviour of tropospheric ozone at Hong Kong, Atmos. Environ., 32, 159-168, 1998.

Center for International Earth Science Information Network (CIESIN), Columbia University; United Nations and Agriculture Programme (FAO); and Cnetro Internacional de Agricultura Tropical (CIAT), Gridded Population of the World: Future Estimates (GWPFE), Palisades, NY. Socioeconomic Data and Ap- plications Center (SEDAC), Columbia University. available online at http://sedac.ciesin.columbia.edu/gpw, last access: 17 July 2009, 2005.

Clarisse, L., Clerbaux, C., Dentener, F., Hurtmans, D., and Coheur, P. F.: Global ammonia distribution derived from infrared satellite observations, Nature Geoscience, 2, 479-483, 2009.

Clerbaux, C., Boynard, A., Clarisse, L., George, M., Hadji-Lazaro, J., Herbin, H., Hurtmans, D., Pommier, M., Razavi, A., Turquety, S., Wespes, C., and Coheur, P.-F.: Monitoring of atmospheric composition using the thermal infrared IASI/MetOp sounder", Atmos. Chem. Phys., 9, 6041-6054, 2009, http://www.atmos-chem-phys.net/9/6041/2009/.

Coheur, P.-F., Barret, B., Turquety, S., Hurtmans, D., Hadji-Lazaro, J., and Clerbaux, C.: Retrieval and characterization of ozone vertical profiles from a thermal infrared nadir sounder, J. Geophys. Res., 110, D24303, doi:10.1029/2005JD005845, 2005.

Ding, A. J., Wang, T., Thouret, V., Cammas, J.-P., and Nédélec, P.: Tropospheric ozone climatology over Beijing: analysis of aircraft data from the MOZAIC program, Atmos. Chem. Phys., 8, 1-13, 2008, http://www.atmos-chem-phys.net/8/1/2008/.

Draxler, R. R. and Rolph, G. D.: HYSPLIT (HYbrid Single-Particle Lagrangian Integrated Trajectory) Model access via NOAA ARL READY Website http://ready.arl.noaa.gov/HYSPLIT.php, NOAA Air Resources Laboratory, Silver Spring, MD, USA, 2010.

Eremenko, M., Dufour, G., Foret, G., Keim, C., Orphal, J., Beekmann, M., Bergametti, G., and Flaud, J.-M.: Tropospheric ozone distributions over Europe during the heat wave in July 2007 observed from infrared nadir spectra recorded by IASI, Geophys. Res. Lett., 35, L18805, doi:10.1029/2008GL034803, 2008.

Fishman, J., Ramanathan, V., Crutzen, P. J., and Liu, S. C.: Tropospheric ozone and climate, Nature, 282, 818-820, 1979.

Fishman, J., Wozniak, A. E., and Creilson, J. K.: Global distribution of tropospheric ozone from satellite measurements using the empirically corrected tropospheric ozone residual technique: Identification of the regional aspects of air pollution, Atmos. Chem. Phys., 3, 893-907, 2003, http://www.atmos-chem-phys.net/3/893/2003/.

Forêt, G., Hamaoui, L., Schmechtig, C., Eremenko, M., Keim, C., Dufour, G., Boynard, A., Coman, A., Ung, A., and Beekmann, M.: Evaluating the potential of IASI ozone observations to constrain simulated surface ozone concentrations, Atmos. Chem. Phys., 9, 8479-8491, 2009,

http://www.atmos-chem-phys.net/9/8479/2009/.

Fortems-Cheiney, A., Chevallier, F., Pison, I., Bousquet, P., Carouge, C., Clerbaux, C., Coheur, P.-F., George, M., Hurtmans, D., and Szopa, S.: On the capability of IASI measurements to inform about CO surface emissions, Atmos. Chem. Phys., 9, 87358743, 2009, http://www.atmos-chem-phys.net/9/8735/2009/.

George, M., Clerbaux, C., Hurtmans, D., Turquety, S., Coheur, P.F. Pommier, M., Hadji-Lazaro, J., Edwards, D. P., Worden, H., Luo, M., Rinsland, C., and McMillan, W.: Carbon monoxide distributions from the IASI/METOP mission: evaluation with other space-borne remote sensors, Atmos. Chem. Phys., 9, 8317-8330, 2009, http://www.atmos-chem-phys.net/9/8317/2009/.

He, Y. J., Uno, I., Wang, Z. F., Pochanart, P., Li, J., and Akimoto, H.: Significant impact of the East Asia monsoon on ozone seasonal behaviour in the boundary layer of Eastern China and the west Pacific region, Atmos. Chem. Phys., 8, 7543-7555, 2008, 
http://www.atmos-chem-phys.net/8/7543/2008/.

Jacob, D. J., Logan, J. A., and Murti, P. P.: Effect of rising Asian emissions on surface ozone in the United States, Geophys. Res. Lett., 26, 2175-2178, 1999.

Jones, D. B. A., Bowman, K. W., Horowitz, L. W., Thompson, A. M., Tarasick, D. W., and Witte, J. C.: Estimating the summertime tropospheric ozone distribution over North America through assimilation of observations from the Tropospheric Emission Spectrometer, J. Geophys. Res., 113, D18307, doi:10.1029/2007JD009341, 2008.

Keim, C., Eremenko, M., Orphal, J., Dufour, G., Flaud, J.-M., Höpfner, M., Boynard, Clerbaux, C., Payan, S., Coheur, P.-F., Hurtmans, D., Claude, H., Dier, H., Johnson, B., Kelder, H., Kivi, R., Koide, T., Lopez Bartolomé, M., Lmabkin, K., Moore, D., Schmidlin, F.J., and Stübi, R.: Tropospheric ozone from IASI: comparison of different inversion algorithms and validation with ozone sondes in the northern middle latitudes, Atmos. Chem. Phys.., 9, 9329-9347, 2009.

Kim, J. H., Lee, H. J., and Lee, S. H.: The characteristics of tropospheric ozone seasonality observed from ozone soudings at Pohang, Korea, Environ. Monit Assess., 118, 1-12, 2006.

Lam, K. S., Wang, T. J., Chan, L.Y., Wang, T., and Harris, J.: Flow patterns influencing the seasonal behaviour of surface ozone and carbon monoxide at a coastal site near Hong Kong, Atmos. Environ., 35, 3121-3135, 2001.

Li, J., Wang, Z., Akimoto, H., Gao, C., Pochanart, P., and Wang, X.: Modeling study of ozone seasonal cycle in lower troposphere over east Asia, J; Geophys. Res., 112, D22S25, doi:10.1029/2006JD008209, 2007.

Lin, W., Xu, X., Zhang, X., and Tang, J.: Contributions of pollutants from North China Plain to surface ozone at the Shangdianzi GAW station, Atmos. Chem. Phys., 8, 5889-5898, 2008, http://www.atmos-chem-phys.net/8/5889/2008/.

Lin, M., Holloway, T., Oki, T., Streets, D. G., and Richter, A.: Mechanisms controlling surface ozone over East Asia: a multiscale study coupling regional and global chemical transport models, Atmos. Chem. Phys., 9, 3277-3301, 2009,

http://www.atmos-chem-phys.net/9/3277/2009/.

Liu, H., Chang, W. L., Oltmans, S. J., Chan, L. Y., and Harris, J. M.: On springtime high ozone events in the lower troposphere from Southeast Asian biomass burning, Atmos. Environ., 33, 24032410, 1999.

Liu, H., Jacob, D. J., Chan, L. Y., Oltmans, S. J., Bey, I., Yantosca, R. M., Harris, J. M., Duncan, B. N., and Martin, R. V.: Sources of tropospheric ozone along the Asian Pacific Rim: an analysis of ozonesonde observations, J. Geophys. Res., 107, 4573, doi:10.1029/2001JD002005, 2002.

Liu, X., Chance, K. V., Sioris, C. E., Spurr, R. J. D., Kurosu, T. P., Martin, R. V., and Newchurch, M. J.: Ozone profile and tropospheric ozone retrievals from Global Ozone Monitoring Experiment: Algorithm description and validation, J. Geophys. Res., 110, D20307, doi:10.1029/2005JD006240, 2005.

Logan, J. A.: An analysis of ozonesonde data for the troposphere: Recommendations for testing 3-D modes and development of gridded climatology for tropospheric ozone, J. Geophys. Res., 105(D2), 16115-16149, 1999.

Marenco, A., Thouret, V., Nedelec, P., Smit, H., Helten, M., Kley, D., Karcher, F., Simon, P., Law, K., Pyle, J., Poschmann, G., Wrede, R. V., Hume, C., and Cook, T.: Measurement of ozone and water vapour by Airbus in-service aircraft: the MOZAIC airborne program, an overview, J. Geophys. Res., 103(D19), 25631-25642, 1998.

Massart, S., Clerbaux, C., Cariolle, D., Piacentini, A., Turquety, S., and Hadji-Lazaro, J.: First steps towards the assimilation of IASI ozone data into the MOCAGE-PALM system, Atmos. Chem. Phys., 9, 5073-5091, 2009,

http://www.atmos-chem-phys.net/9/5073/2009/.

McPeters, R. D., Labow, G. J., and Logan, J. A.: Ozone climatological profiles for satellite retrieval algorithms, J. Geophys. Res., 112, D05308, doi:10.1029/2005JD006823, 2007.

Monks, P. S.: A review of the observations and origins of the spring ozone maximum, Atmos. Environ., 34, 3545-3561, 2000.

Naja, M. and Akimoto, H.: Contribution of regional pollution and long-range transport to the Asia-Pacific region: Analysis of long-term ozonesonde data over Japan, J. Geophys. Res., 109, D21306, doi:10.1029/2004JD004687, 2004.

Oltmans, S. J., Lefohn, A. S., Harris, J. M., Galbally, I., Scheel, H. E., Bodeker, G., Brunke, E., Claude, H., Tarsick, D., Johnson, B. J., Simmonds, P., Shadwick, D., Anlauf, K., Hayden, K., Schmidlin, F., Fujimoto, T., Akagi, K., Meyer, C., Nichol, S., Davies, J., Redondas, A., and Cuevas, E.: Long-term changes in tropospheric ozone, Atmos. Environ., 40, 3156-3173, 2006.

Penkett, S. A. and Brice, K. A.: The spring maximum in photooxidants in the Northern Hemisphere troposphere, Nature, 319, 655-658, 1986.

Penkett, S. A., Blake, N. J., Lightmann, P., Mardr, A. R. W., Ancoyl, P., and Butcher, G.: The seasonal variation of nonmethane hydrocarbons in the free troposphere over the North Atlantic Ocean: possible evidence for extensive reaction of hydrocarbons with the nitrate radical, J. Geophys. Res., 98, 2865-2885, 1993.

Pochanart, P., Akimoto, H., Kaji, Y., and Sukasem, P.: Regional background ozone and carbon monoxide variations in remote Siberia/East Asia, J. Geophys. Res., 108(D1), 4028, doi:10.1029/21001JD001412, 2003.

Richter, A., Burrows, J. P., Nub, H., Granier, C., and Niemeier, U.: Increase in tropospheric nitrogen dioxide over China observed from space, Nature, 437, 129-132, 2005.

Rolph, G.D.: Real-time Environmental Applications and Display sYstem (READY) Website (http://ready.arl.noaa.gov), NOAA Air Resources Laboratory, Silver Spring, MD, USA, 2010.

Rothman, L. S. , Jacquemart, D., Barbe, A., Chris Benner, D., Birk, M., Brown, L. R., Carleer, M. R., Chackerian Jr., C., Chance, K., Coudert, L. H., Dana, V., Devi, V. M., Flaud, J.-M., Gamache, R. R., Goldman, A., Hartmann, J.-M., Jucks, K. W., Maki, A. G., Mandin, J.-Y., Massie, S. T., Orphal, J., Perrin, A., Rinsland, C. P., Smith, M. A. H., Tennyson, J., Tolchenov, R. N., Toth, R. A., Vander Auwera, J., Varanasi, P., and Wagner, G.: The HITRAN 2004 molecular spectroscopic database, J. Quant. Spectrosc. Rad. Transf., 96, 139-204, 2005.

Seinfeld, J. H. and Pandis, S. N.: Atmospheric Chemistry and Physics, from Air Pollution to

Climate Change, John Wiley \& Sons Inc., Toronto, Canada, 792 pp., 1997.

Stiller, G. P. (ed) with contributions from v. Clarmann, T., Dudhia, A., Echle, G., Funke, B., Glatthor, N., Hase, F., H“opfner, M., Kellmann, S., Kemnitzer, H., Kuntz, M., Linden, A., Linder, M., Stiller, G. P., and Zorn, S.: The Karlsruhe Optimized and Precise Radiative Transfer Algorithm (KOPRA), vol. FZKA 6487 of 
Wissenschaftliche Berichte, Forschungszentrum Karlsruhe, Germany, 672 pp., available online at: http://www-imk.fzk.de/asf/ ame/publications/kopra_docu/, 2000.

Tikhonov, A.: On the Solution of Incorrectly Stated Problems and a Method of Regularisation, Dokl. Acad. Nauk SSSR, 151, 501504, 1963.

Turquety, S., Hadji-Lazaro, J., and Clerbaux, C.: First satellite ozone distributions retrieved from nadir highresolution infrared spectra, Geophys. Res. Lett., 29, 2198, doi:10.1029/2002GL016431, 2002.

Turquety, S., Hurtmans, D., Hadji-Lazaro, J., Coheur, P.-F., Clerbaux, C., Josset, D., and Tsamalis, C.: Tracking the emission and transport of pollution from wildfires using the IASI CO retrievals: analysis of the summer 2007 Greek fires, Atmos. Chem. Phys., 9, 4897-4913, 2009,

http://www.atmos-chem-phys.net/9/4897/2009/.

Vingarzan, R.: A review of surface ozone background levels and trends, Atmos. Environ., 38, 3431-3442, 2004.

Wang, T., Wei, X. L., Ding, A. J., Poon, C. N., Lam, K. S., Li, Y. S., Chan, L. Y., and Anson, M.: Increasing surface ozone concentrations in the background atmosphere of Southern China, 19942007, Atmos. Chem. Phys., 9, 6217-6227, 2009, http://www.atmos-chem-phys.net/9/6217/2009/.
Worden, H. M., Logan, J. A., Worden, J. R., Beer, R., Bowman, K., Clough, S. A., Eldering, A., Fisher, B. M., Gunson, M. R., Herman, R. L., Kulawik, S. S., Lampel, M. C., Luo, M., Megretskaia, I. A., Osterman, G. B., and Shephard, M. W.: Comparisons of Tropospheric Emission Spectrometer (TES) ozone profiles to ozonesondes: Methods and initial results, J. Geophys. Res., 112, D03309, doi:10.1029/2006JD007258, 2007.

Worden, H. M., Bowman, K. W., Eldering, A., and Beer, R.: Satellite measurements of the clear-sky greenhouse effect from tropospheric ozone, Nature Geoscience, 1, 305-308, doi:10.1038/ngeo182, 2008.

$\mathrm{Xu}, \mathrm{J} ., \mathrm{Zhu}, \mathrm{Y}$. , and Li, J.: Seasonal cycles of surface ozone and $\mathrm{NO}_{\mathrm{x}}$ in Shanghai, J. Appl. Meteorol., 36, 1424-1429, 1997.

Zbinden, R. M., Cammas, J. P., Thouret, V., Nedelec, P., Karcher, F., and Simon, P.: Mid-latitude tropospheric ozone columns from the MOZAIC program: climatology and inter-annual variability, Atmos. Chem. Phys., 6, 1053-1073, 2006, http://www.atmos-chem-phys.net/6/1053/2006/. 